\title{
Tumour necrosis factor $\alpha$ changes porcine intestinal ion transport through a paracrine mechanism involving prostaglandins
}

\author{
H M Kandil, H M Berschneider, R A Argenzio
}

\begin{abstract}
Prostaglandins stimulate electrogenic anion secretion and inhibit sodium chloride absorption in cryptosporidium induced pig diarrhoea. Because tumour necrosis factor $\alpha(T N F \alpha)$ is an early mediator of inflammation and stimulates prostaglandin secretion, we investigated its effect on intestinal ion transport. Cryptosporidium infected pig ileum showed higher macrophage infiltration and tissue TNF $\alpha$-like activity than uninfected tissues $(p<0.05, n=4$ and $p<0.05$, $n=12$, respectively). TNF $\alpha$ treatment of control porcine ileal mucosa increased the short circuit current (Isc), a measurement of net anion secretion in this model $(p<0 \cdot 001, n=23)$. This effect was blocked by $10^{-6} \mathrm{M}$ indomethacin and $\mathrm{Cl}^{-}$replacement. Neither acute treatment nor preincubation of colonic intestinal epithelial cell monolayers (T84) with TNF $\alpha$ stimulated the Isc. However, co-mounting of TNF $\alpha$ preincubated pig jejunal fibroblasts (P2JF) monolayers back to back with untreated T84 monolayers dosedependently induced an indomethacin sensitive increase in Isc compared with values in untreated co-mounted monolayers $(p<0.001, n=11)$. These data suggest that in infectious diarrhoea, TNF $\alpha$ may induce $\mathrm{Cl}^{-}$secretion through a paracrine mechanism involving prostaglandin release from subepithelial cells, for example fibroblasts.

(Gut 1994; 35: 934-940)
\end{abstract}

Center for

Gastrointestinal

Biology and Disease

and Department of

Anatomy,

Physiological Sciences

and Radiology, College

of Veterinary

Medicine, North

Carolina State

University, USA

H M Kandil

H M Berschneider

R A Argenzio

Correspondence to:

Dr R A Argenzio,

Department of Anatomy,

Physiological Sciences and

Radiology, College of

Veterinary Medicine, North
Carolina State University,

4700 Hillsborough Street, at

William Moore Drive,

Raleigh, NC 27606.

Accepted for publication

29 October 1993
Recent evidence indicates an intimate interaction between the immune, enteric-neural, and endocrine systems and mesenchymal cells in the regulation of intestinal water and electrolyte transport. ${ }^{12}$ Several mediators of immune and inflammatory reactions, such as prostaglandins and reactive oxygen metabolites, stimulate $\mathrm{Cl}^{-}$secretion and inhibit $\mathrm{NaCl}$ absorption in a colonic epithelial cell line, pig ileum, and rat colon. ${ }^{1-6}$ Increased prostaglandin concentrations in the ileum of cryptosporidium infected pigs have recently been implicated in the pathophysiology of diarrhoea induced in this model through the inhibition of $\mathrm{NaCl}$ absorption and stimulation of $\mathrm{Cl}^{-}$secretion. ${ }^{7}$

The cytokine, tumour necrosis factor $\alpha$ (TNF $\alpha$ ), a $17 \mathrm{kDa}$ protein secreted mainly by macrophages, ${ }^{8}$ modulates various functions of cells involved in inflammatory reactions, host defense, and tissue repair. It is believed to be a key mediator of inflammatory reactions and may be a very proximal step in the immune reaction cascade. It is a chemoattractant of neutrophils and macrophages, ${ }^{910}$ and induces the secretion of prostaglandins and reactive oxygen metabolites from several cell lines such as human skin fibroblasts and endothelial and mesangial cells. ${ }^{11-17}$ Several reports indicate an increase in TNF $\alpha$ protein and mRNA in patients with inflammatory bowel disease, ${ }^{18-21}$ although similar changes were undetectable in other studies. ${ }^{22-24}$ One of the reasons for this inconsistency may be the degradation of TNF $\alpha$ by proteases in inflamed tissue. ${ }^{25}$ The effect of TNF $\alpha$ on intestinal ion transport and its role in the pathogenesis of infectious diarrhoea, however, have not been reported.

Assuming that $\mathrm{TNF} \alpha$ stimulates prostaglandin secretion from intestinal cells as it does from cells of other tissues, we suggest that increased $\mathrm{TNF} \alpha$ values in infections and inflammation modulate intestinal electrolyte transport. Moreover, as the lamina propria and submucosa are the main source of prostaglandin, ${ }^{26-28}$ we postulated that the effect of TNF $\alpha$ on electrolyte fluxes across the intestinal epithelium is mediated through the release of other inflammatory mediators, such as prostaglandin, from subepithelial mesenchymal cells which subsequently modulate epithelial cell function in a paracrine fashion.

\section{Methods}

REAGENTS AND ANIMALS

Recombinant human TNF $\alpha$ ( $r T N F \alpha)$ was obtained from Boehringer Mannheim Biochemicals (Indianapolis, In 46250) and primary monoclonal anti-porcine macrophage antibody from American Type Culture Collection (Rockville, MD). Zymed streptavidin-biotin system for immunohistological staining of macrophages was obtained from Zymed Laboratories Inc (San Francisco, CA 94080) and human TNF $\alpha$ ELISA kit from Genzyme Corporation (Cambridge, MA 02139). All other chemicals were obtained from Sigma Chemical Co (St Louis, MO 63178).

Study piglets were obtained from the CGIBD Barrier Intact Piglet Facility at NCSU, College of Agriculture. Animals were prevented access to the sow after birth to prevent transmission of passive immunisation and were fed $12.5 \mathrm{ml} / \mathrm{kg} / \mathrm{h}$ artificial formula with an automatic feeding device (Autosow). ${ }^{29}$ 
Some animals were infected with $10^{8}$ Cryptosporidium parvum oocysts on day 3 of life as previously described. ${ }^{30}$ Rectal swabs were taken daily for determination of cryptosporidia oocytes and rotavirus. ${ }^{30}$ All infected animal stools were positive for cryptosporidia and showed histological indication of infection. ${ }^{30}$ All animal stools were negative for rotavirus and control animal stools were negative for cryptosporidia. Both infected and control animals were killed three to five days after inoculation (peak infection) by intracardiac injection of 2-4 $\mathrm{g}$ of sodium pentobarbital. Preanaesthesia with $50-70 \mathrm{mg}$ intramuscular ketamine was given.

\section{TNF $\alpha$ EXTRACTION}

After stripping the muscle layer, $4 \mathrm{~cm}$ of ileum were homogenised, in phosphate buffered saline (PBS) with $1 \%$ bovine serum albumin and $1 \mu \mathrm{g} / \mathrm{ml}$ of each of antipain, aprotinin, leupeptin and pepstain A, and $1 \mathrm{mM}$ PMSF as previously described for interleukin 1 extraction. ${ }^{31}$ An ELISA using anti-rTNF $\alpha$ antibody was used to determine porcine $\mathrm{TNF} \alpha$ values. rTNF $\alpha$ has $80 \%$ homology with porcine $\mathrm{TNF} \alpha$, and anti-rTNF $\alpha$ has been reported to cross react with porcine $\mathrm{TNF} \alpha$, blocking $97 \%$ of its activity. ${ }^{32} 33$

To validate the extraction procedure, we determined the recovery of $\mathrm{rTNF} \alpha(150,300$, or $600 \mathrm{pg} / \mathrm{ml}$ ) added to homogenised ileal tissues from control animals. The mean (SEM) recovery was $73(10) \%$, compared with $36(18) \%$ when tissues were homogenised in PBS $(n=12)$. The observed TNF $\alpha$ value was highly correlated with the expected concentrations, indicating the absence of any significant interference $(R=0 \cdot 84)$.

\section{MACROPHAGE COUNTING}

Macrophages were immunohistologically stained utilising the mouse IgG1; 74-22-15 as the primary anti-porcine macrophage antibody. ${ }^{34}$ The number of macrophages and the surface area of five consecutive lamina propriae from each histological slide were measured by the same observer, who was blinded according to the experimental protocol. Measurements were done with a video imaging morphometric system (ImagePro II, Media Cybernetics, Silver Spring, MD). Images were captured from a Nikon Microphot-FXA with a Javelin 3452RGB television camera.

\section{IN VITRO TRANSPORT STUDIES}

The distal $25 \mathrm{~cm}$ of the ileum were removed, submerged in Ringer's solution, opened along the antimesenteric border for stripping of the muscle layer, and then mounted on Ussing chambers exposing $1.13 \mathrm{~cm}^{2}$. For tissues used to test the effect of indomethacin on the TNFa effect, stripping was carried out in oxygenated buffer with $1 \mu \mathrm{M}$ indomethacin. As an energy source, $10 \mathrm{mM}$ glutamine was added to the serosal side and equimolar mannitol on the mucosal side of mounted tissues. The buffer contained $(\mathrm{mM}) 140 \mathrm{Na}^{+}, 5 \cdot 2 \mathrm{~K}^{+}, 1 \cdot 2 \mathrm{Ca}^{++}$, $1.2 \mathrm{Mg}^{++}, 119.8 \mathrm{Cl}^{-}, 25 \mathrm{HCO}_{3}{ }^{-}, 0.4$ $\mathrm{H}_{2} \mathrm{PO}_{4}{ }^{-}$, and $2 \cdot 4 \mathrm{HPO}_{4}{ }^{--}, \mathrm{pH} 7 \cdot 4$ when gassed with $95 \% \quad \mathrm{O}_{2} / 5 \% \quad \mathrm{CO}_{2}$. Bathing solutions were circulated through a water jacket and were maintained at $37^{\circ} \mathrm{C}$. The spontaneous potential difference (PD) was short circuited by an automatic voltage clamp (World Precision Instruments, New Haven, $\mathrm{CN})$ that corrected for fluid resistance. Tissues were continuously short circuited (except when the spontaneous PD was read every 30 minutes) using $\mathrm{AG}-\mathrm{AgCl}$ electrodes connected to bathing solutions via agar bridges. Short circuit current (Isc), which is the current automatically applied to short circuit the PD to zero, was recorded every 10 minutes. Conductance (G) was calculated based on Ohm's law using Isc and spontaneous $\mathrm{PD}$ or, if $\mathrm{PD}$ was $< \pm 1 \mathrm{mV}$, a clamped Isc of $\pm 100 \mu \mathrm{A}$ and the corresponding PD. Tissues were allowed to equilibrate for 20 or 90 minutes before early and late experiments, respectively.

rTNF $\alpha$ was added to the serosal side of ileal segments in the Ussing chamber and compared with matched control tissue from adjacent ileal segments from the same animal. A $10^{-6} \mathrm{M}$ serosal prostaglandin $\mathrm{E}_{2}\left(\mathrm{PGE}_{2}\right)$ treated tissue was included in some studies to test the ability of the tissue to respond to secretory stimuli. In addition, at the end of each study, the effect of $10 \mathrm{mM}$ mucosal glucose on the Isc was measured as an indication of tissue viability. The maximum increases in Isc from the pretreatment level (Isc-max) in response to $\mathrm{TNF} \alpha$ and $\mathrm{PGE}_{2}$ during a 60 minute follow up period were compared with the corresponding changes in time matched control tissues from the same animal.

\section{CELL LINES AND CULTURE TECHNIQUES}

T-84 cells, an established colonic carcinoma cell model of active intestinal $\mathrm{Cl}^{-}$secretion, ${ }^{35}$ and pig jejunal fibroblasts, $\mathrm{P} 2 \mathrm{JF},{ }^{36}$ were plated in $100 \mathrm{~mm}^{2}$ Corning tissue culture plates at a seeding density of about $10^{8}$ cells per plate and incubated at $37^{\circ} \mathrm{C}$ in $5 \% \mathrm{CO}_{2}-95 \%$ air with $98 \%$ humidity in a water jacketed incubator. The growth media for T-84 cells was Dulbecco's minimum essential media (DMEM/F12) with 5\% fetal calf serum (FCS). For P2JF fibroblast cells, DMEM/F12 with $10 \%$ FCS was used. Media were replaced every three to four days. Upon reaching confluence, the cell monolayers were subcultured (1:3) using $0.1 \%$ trypsin- $1.4 \mathrm{mM}$ EDTA solution, every seven to 14 days. For electrical studies, cells were trypsinised and then plated on $25 \mathrm{~mm}$ polycarbonate filters, with $5 \mu \mathrm{m}$ pores (Nucleopore filters, VWR Scientific) which had been coated with rat tail collagen and glued to plastic rings. ${ }^{35} 37$ One $\mathrm{ml}$ of medium, containing approximately $10^{6}$ cells, was placed in each ring structure with a surface area of $2.98 \mathrm{~cm}^{2}$. The rings were supported on $3 \mathrm{~mm}$ glass beads in culture dishes containing the appropriate culture medium, which was 
TABLE I Increased tumour necrosis factor $\alpha(T N F \alpha)$ immune activity and macrophage infiltration in the ileum in cryptosporidium induced diarrhoea

\begin{tabular}{lcl}
\hline & $\begin{array}{c}\text { Macrophages/mm } \\
\text { of lamina propria }\end{array}$ & $\begin{array}{l}T N F \alpha \\
\text { (pg/mg protein) }\end{array}$ \\
\hline $\begin{array}{l}\text { Control (mean (SEM)) } \\
\text { Infected (mean (SEM) }\end{array}$ & $50 \pm 26$ & $297(34)$ \\
\hline
\end{tabular}

Frozen sections were obtained from the terminal ileum of control and infected piglets and immunohistologically stained for macrophages using the streptavidin-biotin method $(n=4)$. For determination of tissue TNF $\alpha$ like activity, $4 \mathrm{~cm}$ of For determination of tissue TNF $\alpha$ like activity, $4 \mathrm{~cm}$ of stripped ileum were homogenised in PBS with $1 \%$ BSA and mixture of antiproteinases (see text). TNF $\alpha$-like activity was

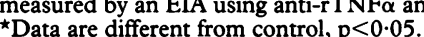

replaced inside and outside the rings every three to four days. Cells were incubated on the rings for seven to 14 days before experimentation. Ring structures with the cultured cell monolayers were mounted in modified Ussing chambers $^{35}$ and the Isc and PD were followed every 10 minutes as described above.

To determine the importance of fibroblasts to the effect of TNF $\alpha$ on the epithelial cell line, monolayers of fibroblasts and epithelial cells were mounted back to back on Ussing chambers so that cell monolayers were spacially separated by $1 \mathrm{~mm}$ but were in contact through the incubation buffer present between the two ring structures. ${ }^{36}$ Cell monolayers were incubated for 24 hours with $\mathrm{TNF} \alpha$ $(0.05$ to $50 \mathrm{ng} / \mathrm{ml})$. After a 40 minute equilibration period, the Isc and PD were recorded for 20 minutes.

\section{STATISTICS}

Data are presented as the maximum change in Isc from pretreatment level in response to treatment (Isc-max). $\Delta$ Isc-max is the difference between Isc-max of treated and time matched control tissues from the same animal. Comparisons of paired data were conducted with a paired $t$ test. A p value of $<0.05$ was considered significant. Data are presented as mean (SEM).

\section{Results}

TNF $\alpha$ INVOLVEMENT IN CRYPTOSPORIDIOSIS DIARRHOEA

As a preliminary indication of the role of $\mathrm{TNF} \alpha$ in the development of infectious diarrhoea we determined the number of macrophages, the main cellular source of $\mathrm{TNF} \alpha$, in the lamina propria and $\mathrm{TNF} \alpha$ like activity in the ileum of cryptosporidium infected pigs versus age and litter matched control animals. As shown in Table I, there

TABLE II Effect of $25 \mathrm{ng} / \mathrm{ml}$ tumour necrosis factor $\alpha$ (TNF $\alpha$ ) on the conductance of normal pig ileum

\begin{tabular}{|c|c|c|c|c|}
\hline \multirow[b]{2}{*}{ Group } & \multicolumn{4}{|c|}{ Time (min) after TNF $\alpha$ treatment (msiemens $/ \mathrm{cm}^{2}$ ) } \\
\hline & 0 & 60 & 120 & 180 \\
\hline $\begin{array}{l}\text { Control (mean (SEM)) } \\
\text { TNF } \alpha \text { (mean (SEM)) }\end{array}$ & $\begin{array}{l}21 \cdot 3(1 \cdot 6) \\
21 \cdot 4(1 \cdot 7)\end{array}$ & $\begin{array}{l}19 \cdot 0(2 \cdot 0) \\
20 \cdot 1(1 \cdot 7)\end{array}$ & $\begin{array}{l}20.0(2.0) \\
19.0(1.8)\end{array}$ & $\begin{array}{l}24 \cdot 8(5 \cdot 5) \\
20 \cdot 5(4 \cdot 1)\end{array}$ \\
\hline
\end{tabular}

TNF $\alpha$ was added to the serosal side of normal piglet ileal tissues 20 minutes after mounting on Ussing chambers. Data are TNF $\alpha$ treated and time matched control tissues from the same Ussing chambimal $(n=7)$. was a significant increase in the concentration of macrophages and TNF $\alpha$ like activity in the ileum of infected animals over control levels $(\mathrm{p}<0.05)$.

\section{TISSUE VIABILITY}

As summarised in Table II, there was no change in tissue conductance during the three hour period of the study, indicating stability of the tissue in vitro. Tissues that showed conductance outside the $95 \%$ confidence interval $(95 \% \mathrm{CI})$ around the mean conductance at baseline were excluded from further analysis. Serosal addition of $10^{-6} \mathrm{M} \mathrm{PGE}_{2}$ to ileal tissues from nine animals one hour after mounting resulted in a Isc-max of 55 (11) $\mu \mathrm{A} / \mathrm{cm}^{2}$. This was not significantly different from the response when $\mathrm{PGE}_{2}$ was added 20 minutes after mounting (73 (7) $\mu \mathrm{A} / \mathrm{cm}^{2}$ ), indicating that the tissue's ability to respond to secretory stimuli was maintained throughout the study. There was, however, a reduction in tissue response to the serosal application of $10^{-6} \mathrm{M} \mathrm{PGE}_{2}$ after three hours (Isc-max $=21$ (10) $\left.\mu \mathrm{A} / \mathrm{cm}^{2}, \mathrm{p}<0 \cdot 01\right)$. All tissues consistently responded to $10 \mathrm{mM}$ mucosal glucose added
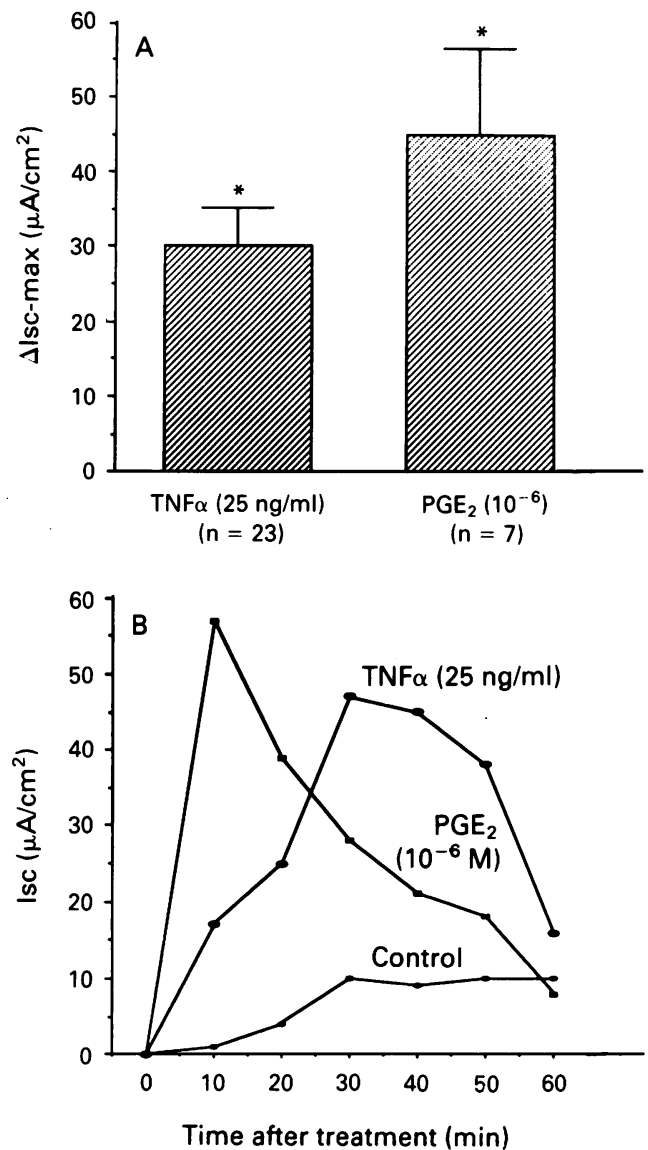

Figure 1: Effect of $25 \mathrm{ng} / \mathrm{ml}$ tumour necrosis factor $\alpha$ (TNF $\alpha$ ) added 20 minutes after mounting on the increase in short circuit current ( $\Delta I s c$ ) of normal pig ileum. TNF $\alpha$ or $P G E_{2}\left(10^{-6}\right)$ were added to the serosal side of stripped ileal tissues and compared with control tissues from the same animal. Isc-max is the maximal change of Isc from pretreatment values in response to treatment. DIsc-max is the difference between Isc-max of treated and time matched control tissues from the same animal. Data are mean (SEM). Isc changes in response to TNF $\alpha$ and prostaglandin $P G E_{2}$ in a representative animal are presented in Figure 1B. * Statistically different from control, $p<0.05$. 


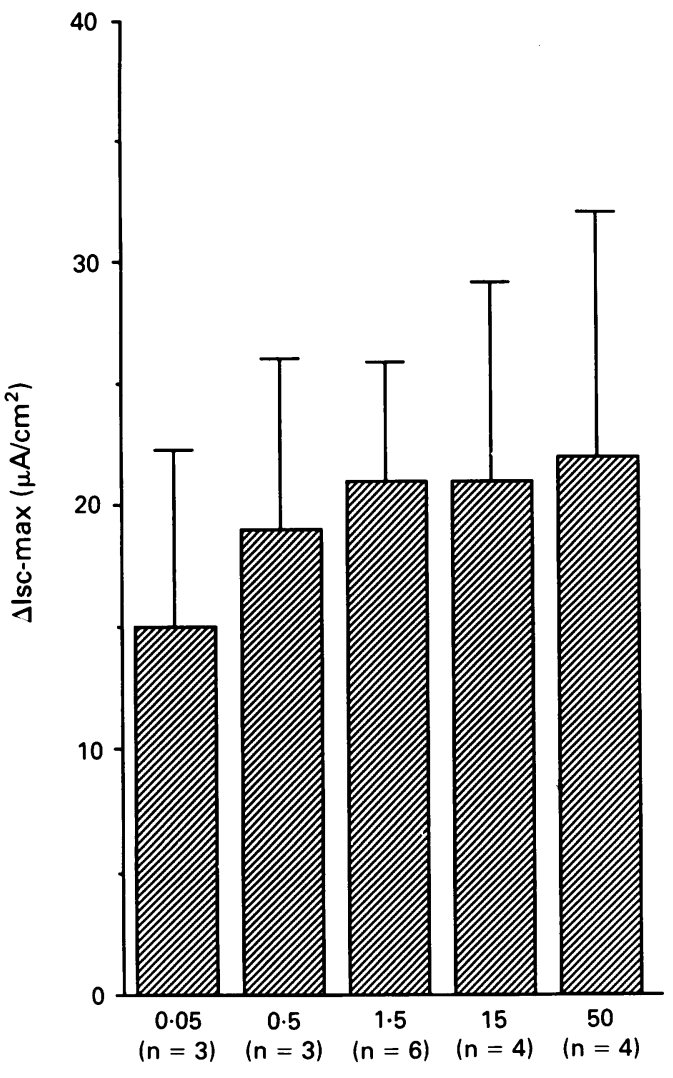

TNF $\alpha$ dose $(\mathrm{ng} / \mathrm{ml})$

Figure 2: $\Delta I s c-$ max dose response of tumour necrosis factor $\alpha(T N F \alpha)$ in normal pig ileum: The indicated doses of

$T N F \alpha$ were added to the serosal side of stripped ileal tissue segments from the same animal 20 minutes after mounting on Ussing chambers. Isc-max is the maximal change of Isc from pretreatment values in response to treatment.

$\Delta I s c-$ max is the difference between Isc-max of treated and time matched control tissues from the same animal. Data are mean (SEM)

at the end of each experiment with an increase in Isc of more than $20 \mu \mathrm{A} / \mathrm{cm}^{2}$.

\section{EFFECT OF TNF $\alpha$ ON ION TRANSPORT}

When the piglet ileum is stimulated with $\mathrm{PGE}_{2}$, there is stimulation of active electrogenic $\mathrm{Cl}^{-}$and $\mathrm{HCO}_{3}{ }^{-}$secretion, reflected by an increase in Isc, as well as inhibition of electroneutral $\mathrm{NaCl}$ absorption. ${ }^{4}$ Figure 1 shows the effect of $25 \mathrm{ng} / \mathrm{ml}$ serosal $\mathrm{rTNF} \alpha$ $\left(2 \times 10^{-7} \mathrm{M}\right)$ on the Isc of normal piglet ileal tissue when added 20 minutes after mounting. TNF $\alpha$ treatment resulted in a significant increase in Isc-max above time matched control levels (42 (6) $v 12$ (3) $\mu \mathrm{A} / \mathrm{cm}^{2}$ ). The $\mathrm{TNF} \alpha$ effect was transient and was observed $30(2.9)$ minutes after treatment, compared with a $\mathrm{PGE}_{2}$ effect of $58(10) \mu \mathrm{A} / \mathrm{cm}^{2}$ consistently observed 10 minutes after treatment (Fig 1). In a graded dose response study, adding 0.05 to $50 \mathrm{ng} / \mathrm{ml} \mathrm{TNF} \alpha$ to the serosal bathing solution showed a threshold effect between 0.5 and $5 \mathrm{ng} / \mathrm{ml}$ (Fig 2).

As shown in Figure 3, the TNF $\alpha$ effect was blocked by indomethacin $\left(10^{-6} \mathrm{M}\right)$ added to both sides of the tissue before treatment with TNF $\alpha \quad(p<0.01, n=5)$ and by $\mathrm{Cl}^{-}$ replacement from the bathing buffer $(p<0.01$, $\mathrm{n}=3$ ), indicating that the TNF $\alpha$ stimulation of Isc was $\mathrm{Cl}^{-}$dependent and related to the

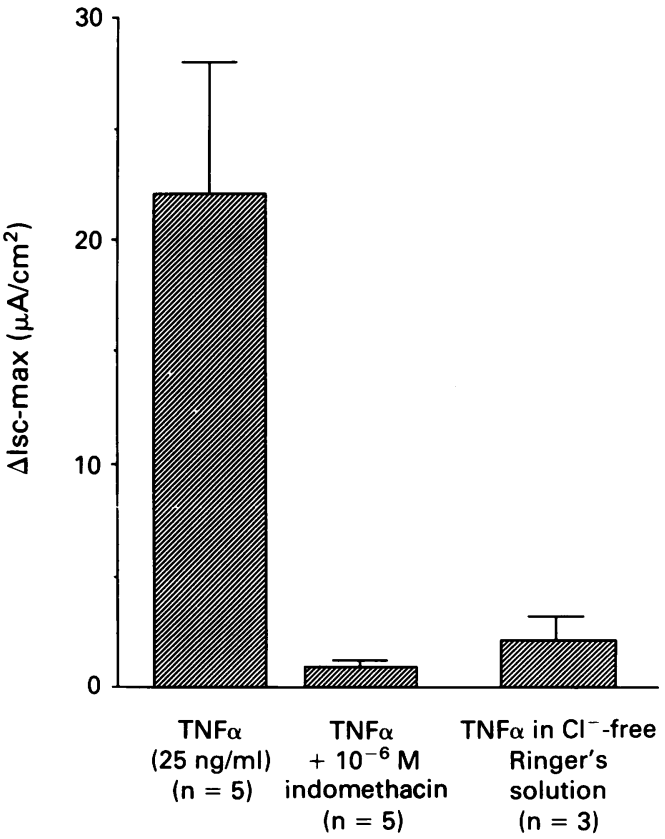

Figure 3: Effect of indomethacin $\left(10^{-6} \mathrm{M}\right)$ and $\mathrm{Cl}^{-}$ replacement on $25 \mathrm{ng} / \mathrm{ml}$ tumour necrosis factor $\alpha(T N F \alpha)$ mediated increase in short circuit current (Isc) in normal pig ileum: TNF $\alpha$ was added to the serosal side of stripped ileal tissue segments from the same animal incubated in normal Ringer's solution, normal Ringer's with $10^{-6} \mathrm{M}$ indomethacin or $\mathrm{Cl}^{-}$-free buffer. Isc-max is the maximal change of Isc from pretreatment values in response to treatment. $\Delta I s c-$ max is the difference between Isc-max of treated and time matched control tissues from the same animal incubated in the same buffer. Data are mean (SEM).

cyclo-oxygenase metabolites of arachidonic acid.

\section{SITE OF TNF $\alpha$ EFFECT}

We were interested in determining whether $\mathrm{TNF} \alpha$ exerts any direct effect on intestinal epithelium or acts mainly through its effect on other mesenchymal tissues. Direct addition of $\mathrm{TNF} \alpha$ to mounted T-84 cell monolayers or fibroblast monolayers comounted with T-84 monolayers had no effect on Isc for up to three hours follow up (data not shown). Parallel studies indicated that $\mathrm{TNF} \alpha$ started to induce P2JF production of $\mathrm{PGE}_{2}$ after 24 hours' incubation (Dr Berschneider; unpublished data). We next compared the Isc across T-84 cell monolayers mounted on Ussing chambers alone or back to back with P2JF monolayers (T84/P2JF) after 24 hours' preincubation with $25 \mathrm{ng} / \mathrm{ml} \mathrm{TNF} \alpha$ of either the T-84 or the P2JF monolayers. Basal Isc was followed for 20 minutes, beginning 40 minutes after mounting, when it reached a steady state. As shown in Figure 4, TNF $\alpha$ preincubation of the T84 monolayers had no effect on the basal Isc across the T84 monolayers, whether mounted alone or with P2JF monolayers. On the other hand, preincubation of the P2JF monolayers induced an increase in basal Isc across the T84/P2JF monolayers compared with that across untreated T84/P2JF monolayers $(9 \cdot 0(1 \cdot 3) v$ $\left.3.9(0.4) \mu \mathrm{A} / \mathrm{cm}^{2}, \mathrm{p}<0.001\right)$. As was the case with pig ileal tissue, the TNF $\alpha$ induced increase in Isc was blocked with $10^{-6} \mathrm{M}$ indomethacin indicating the involvement of 


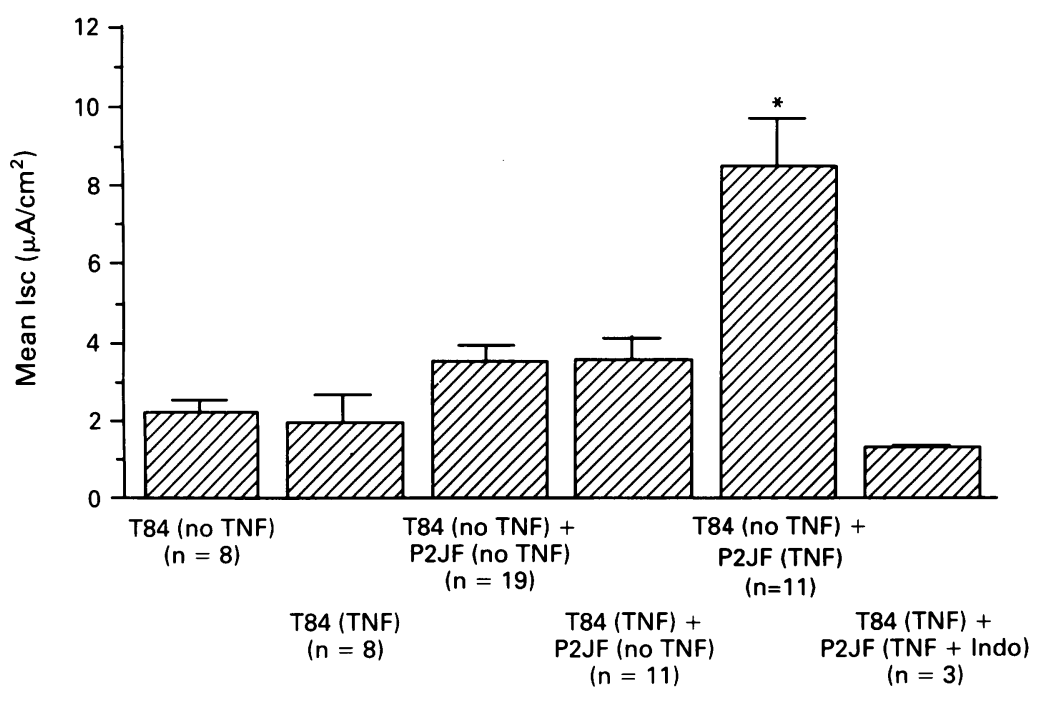

Figure 4: Effect of incubation of T-84-cell or fibroblast monolayers with TNF $\alpha$ for 24 hours before mounting on Ussing chambers on short circuit current (Isc) across T-84/PF2F. For 24 hours before mounting, either T-84 cell or fibroblast monolayers were incubated with TNF $\alpha(25 \mathrm{ng} / \mathrm{ml})$. After 40 minutes' equilibration, Isc was followed for 20 minutes. Isc was averaged over the 20 minute follow up period. Data are mean (SEM). ${ }^{\star}$ Statistically different from control, $T 84$ (no TNF) $+P 2 \mathcal{F} G$ (no TNF), $p<0.05$.

cyclo-oxygenase metabolites of arachidonic acid in mediating TNF $\alpha$ effect (Fig 4).

\section{DOSE RESPONSE OF TNF $\alpha$ ON ISC OF} T-84/FIBROBLASTS

Monolayers of fibroblasts were incubated with 0.01 to $50 \mathrm{ng} / \mathrm{ml} \mathrm{TNF} \alpha$ for 24 hours before mounting back to back with untreated T-84 cell monolayers. As shown in Figure 5, a threshold between 0.5 and $1 \mathrm{ng} / \mathrm{ml}$ was observed with a maximum increase of basal Isc at $25 \mathrm{ng} / \mathrm{ml} \mathrm{TNF} \alpha$.

\section{Discussion}

To our knowledge this is the first study to show

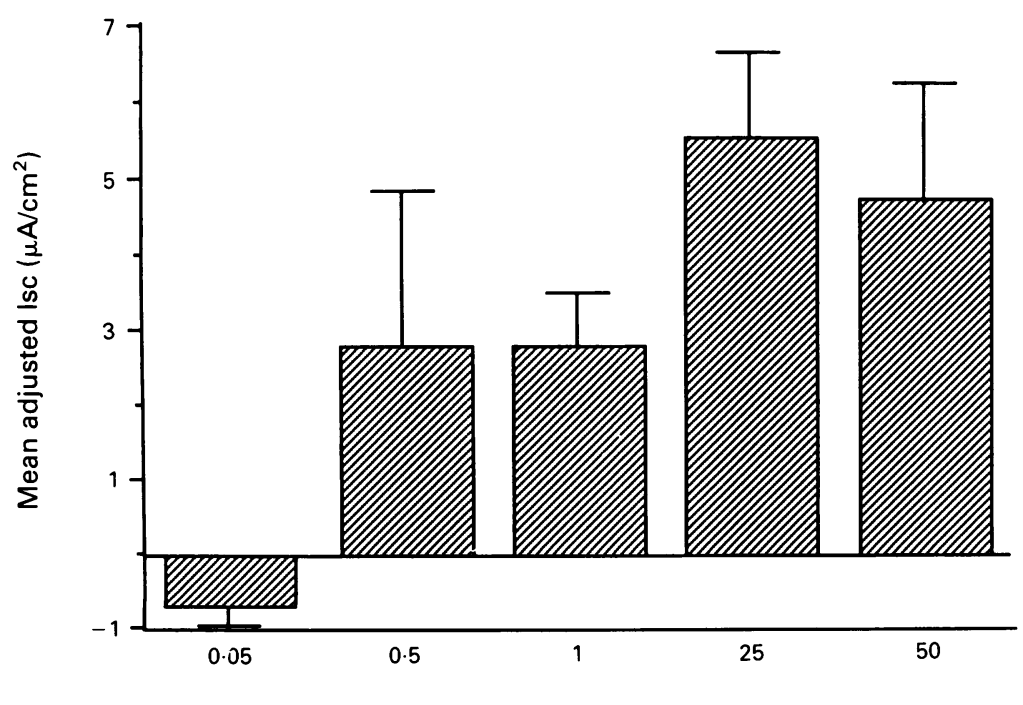

$\mathrm{TNF} \alpha$ dose $(\mathrm{ng} / \mathrm{ml})$

Figure 5: Dose effect of 24 hours' incubation of fibroblast monolayers with tumour necrosis factor $\alpha(T N F \alpha)$ on short circuit current (Isc) across $T-84 / P \mathcal{F} 2 F$. Each group consisted of T-84 cell monolayers mounted on Ussing chambers back to back with fibroblast (PF2F) monolayers (T-84/PF2F). For 24 hours before mounting, fibroblast monolayers were incubated with the indicated TNF $\alpha$ doses. After 40 minutes' equilibration, Isc was followed for 20 minutes. Isc was averaged over the 20 minute follow up period. Adjusted Isc is the difference between Isc of treatment and control T-84/PF2F monolayers. Data are presented as mean (SEM). the effect of TNF $\alpha$ on intestinal epithelial cell ion transport. Our data show that serosal application of $\mathrm{rTNF} \alpha$ to normal piglet ileal tissues mounted on Ussing chambers stimulated an increase in Isc that was significantly higher than that observed for control ileal tissues from the same animals, indicating a TNF $\alpha$ effect on electrogenic ion transport. These data, in addition to the increased $\mathrm{TNF} \alpha$-like activity and macrophage infiltration in cryptosporidium induced diarrhoea, suggest a role for $\mathrm{TNF} \alpha$ in the diarrhoea developed in this model.

The pathophysiological role of $\mathrm{TNF} \alpha$ in intestinal tissue inflammation is still controversial. Some reports indicate an increase in $\mathrm{TNF} \alpha$ protein and mRNA in patients with inflammatory bowel disease, ${ }^{18-21}$ although similar changes were undetectable in other studies. $^{22-24}$ It has been suggested that the inability to detect any $\mathrm{TNF} \alpha$ increase in the latter reports may be due to the following: (a) therapy, such as corticosteroids, that may inhibit TNF $\alpha$ level; (b) the method of TNF $\alpha$ measurement; Olson et al ${ }^{19}$ used immunohistochemical staining rather than measurement of TNF $\alpha$ in homogenised tissue; (c) the possibility that younger subjects express more $\mathrm{TNF} \alpha$; and (d) $\mathrm{TNF} \alpha$ degradation by proteases in inflamed tissue. ${ }^{25}$ Our data indicate that the addition of antiproteases to homogenisation buffer is important for the detection of tissue TNF $\alpha$ activity.

Several reports indicate a stimulatory effect of TNF $\alpha$ on the secretion of prostaglandins, ${ }^{11}{ }^{15-17}$ although the TNF $\alpha$ effect on intestinal production of prostaglandins has not been previously reported. Our data indicate the involvement of prostaglandins in the TNF $\alpha$ mediated effect on Isc. Firstly, most of the TNF $\alpha$ mediated changes in ion transport, both in ileal tissues and T-84 cell/fibroblast model, were blocked by $10^{-6} \mathrm{M}$ indomethacin, a blocker of prostaglandin synthesis through inhibition of cyclo-oxygenase enzyme. Although indomethacin has been reported to have unspecific effects other than cyclooxygenase inhibition, such as inhibiting $\mathrm{K}^{+}$ stimulated ATPase and $\mathrm{Ca}^{++}$uptake, higher concentrations have been required to elicit these effects than those needed for the inhibition of prostaglandin production. ${ }^{39} 40$ Secondly, incubation of the porcine intestinal fibroblasts, P2JF, with TNF $\alpha$ significantly increased the $\mathrm{PGE}_{2}$ level in the culture media (Dr Berschneider; unpublished data), further indicating prostaglandin involvement in the TNF $\alpha$ effect.

The increase of Isc in response to TNF $\alpha$ is most probably mediated by electrogenic $\mathrm{Cl}^{-}$ secretion. Firstly, the $\mathrm{PGE}_{2}$ induced increase of Isc in piglet ileum has previously been shown to be mediated by electrogenic $\mathrm{Cl}^{-}$ secretion. ${ }^{4}$ Secondly, $\mathrm{Cl}^{-}$replacement from the bathing buffer blocked the TNF $\alpha$ stimulation of Isc. Thirdly, the observed increase of Isc in T84 cells generally reflects electrogenic $\mathrm{Cl}^{-}$secretion. ${ }^{35}$

Our data indicate that the effect of TNF $\alpha$ on epithelial cells is indirect. TNF $\alpha$ preincubation 


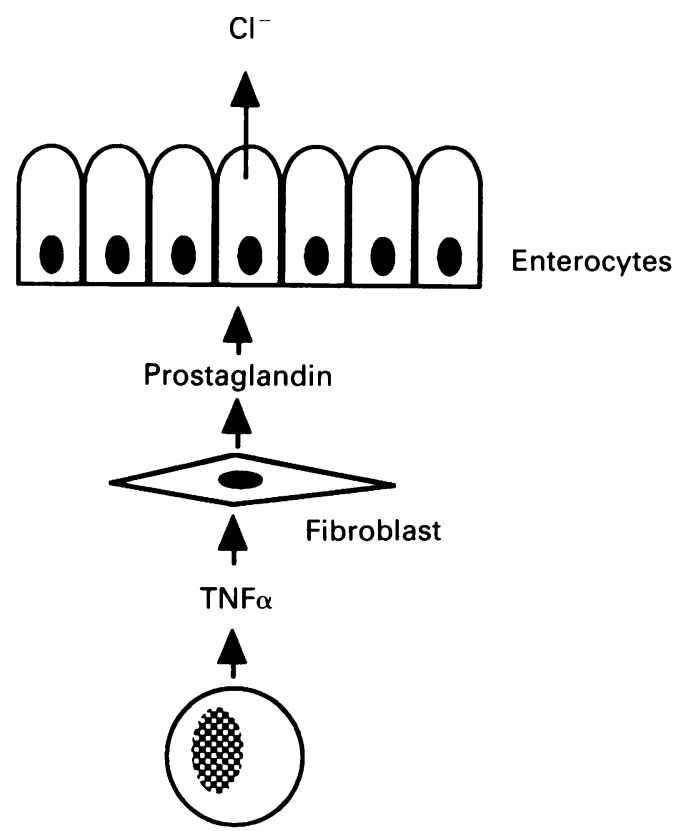

Mononuclear cell

Figure 6: Proposed mechanism of TNF $\alpha$ modulation of ion transport across the intestinal epithelial cells. We postulate a chain of events where: (1) TNF $\alpha$ and probably other cytokines are released early in intestinal infectious and inflammatory disorders. (2) Cytokines act on subepithelial intestinal cells to release other inflammatory mediators such as prostaglandins. (3) Prostaglandins act on the intestinal epithelial cells changing ion transport and inducing diarrhoea. Modified from Bern et al. (J Clin Invest 1989; 83: $1810-20$.)

of the epithelial cell line T-84 had no effect on Isc whether mounted alone or co-mounted with untreated control fibroblast monolayers. It was only when $\mathrm{T}-84$ cell monolayers were co-mounted with fibroblast monolayers which had been preincubated with TNF $\alpha$ for 24 hours, that an increase in Isc was observed. Because co-mounted monolayers in this system do not have any direct contact $^{37}$ the increase in Isc across epithelial cells co-mounted with fibroblasts is mediated by products released from fibroblasts in response to preincubation with $\mathrm{TNF} \alpha$. Major candidates for mediating this effect are prostaglandins, although other mediators may also be involved. This indicates an important intercellular communication in mediating the $\mathrm{TNF} \alpha$ effect on intestinal epithelial cells. Intercellular communication has recently been reported in cells from the same line - that is, glomerular mesangial cells, where cells activated with $\mathrm{TNF} \alpha$ may release stimulant(s) that affect adjacent cells ${ }^{4142}$ and a paracrine modulation of the intestinal and renal epithelial function by fibroblasts and endothelial cells, respectively, has been suggested. ${ }^{35} 37$ In addition, the data by Lawson et al, Smith et al, and Craven et al ${ }^{26-28}$ indicating that most of the prostaglandin production is in the submucosa, whereas the prostaglandin effect is mainly on the epithelium, supports the existence of such a paracrine mode of action in the intestine.

There is growing evidence for the importance of interactions between different inflammatory mediators in the development of maximum immune mediated reactions. This 'priming' effect has been reported between TNF $\alpha$ and other cytokines such as interleukin 1 (IL-1). ${ }^{11} 4546$ Recent preliminary data by Berschneider and Goralska indicate the presence of a synergistic interaction between $\mathrm{TNF} \alpha$ and IL-1 in stimulating increased Isc across T-84 cells. ${ }^{47}$ Synergistic interaction between $\mathrm{TNF} \alpha$ and IL-1 in stimulating the fibroblast secretion of $\mathrm{PGE}_{2}$ has been reported $^{11}$ and P2JF cells primed with IL-1 show a faster induction of $\mathrm{PGE}_{2}$ synthesis in response to $\mathrm{TNF} \alpha$ than unprimed cells (Dr Berschneider; unpublished data). Priming or synergistic interaction between TNF $\alpha$ and the immune cells, other cytokines, or the submucosal enteric nerve plexuses may be the reason for the faster response of whole tissues than that of the cell culture model to TNF $\alpha$ in our study.

In conclusion, we suggest a role for TNF $\alpha$ in the pathophysiology of infectious diarrhoea induced in a model of cryptosporidiosis infection in the pig. We postulate a chain of events where: (1) TNF $\alpha$ and probably other cytokines are released early in intestinal infectious and inflammatory disorders; (2) cytokines act on subepithelial intestinal cells to release other inflammatory mediators such as prostaglandins; and (3) prostaglandins act on the intestinal epithelial cells altering ion transport and inducing diarrhoea (Fig 6).

Supported by grants R01-Dk40584 and P30-DK34987 from the National Institute of Health, NRICGP \# 91-372046411 from the US Department of Agriculture and by technical support by the Immunoassay Core of the CGIBD, University of North Carolina at Chapel Hill. Some of the data have been reported in an abstract form (Gastroenterology 1992; 102: A217).

1 Powell DW. Immunology of intestinal electrolyte transport. In: Schultz SG, Field M, Frizzell RA, Rauner BB, eds. Handbook of physiology, Section 6. Baltimore: Waverly Press, 1991: 591-642.

2 Bern MJ, Sturbaum W, Karayalan SS, Berschneider HM, Wachsman JT, Powell DW. Immune system control of rat and rabbit colonic electrolyte transport: role of prostaglandins and enteric nervous system. 7 Clin Invest 1988; 83: 1810-20.

3 Weymer A, Hyott P, Liu W, McRoberts JA, Dharmsathaphorn K. Chloride secretory mechanisms induced by prostaglandin $E_{1}$ in colonic epithelial cell line. I Clin Invest 1985; 76: 1828-36.

4 Argenzio RA, Liacos JA. Endogenous prostanoids control ion transport across neonatal porcine ileum in vitro. Am f Vet Res 1990; 51: 747-51.

5 Rawson LC, Binder HJ. Effect of prostaglandins on ion transport across isolated colonic mucosa. Dig Dis $\mathrm{Sci}$ 1980; 25: 900-4.

6 Karayalcin SS, Sturbaum CW, Wachsman JT, Cha JH, Powell DW. Hydrogen peroxide stimulates rat colonic prostaglandin production and electrolyte transport. $\Im$ Clin Invest 1990; 86: 60-8.

7 Argenzio RA, Leece J, Powell DW. Prostaglandins inhibit intestinal $\mathrm{NaCl}$ absorption in experimental cryptosporidiosis. Gastrointerology 1993; 104: 440-7.

8 Nedwin GE, Svedersky LP, Bringman TS, Palladino MA, Goeddel DV. Effect of interleukin-2, interferon gamma and mitogen on the production of tumor necrosis factorsalpha and beta. F Immunol 1985; 135: 2492-7.

9 Furie MB, McHugh DD. Migration of neutrophils across endothelial monolayers is stimulated by treatment of the monolayers with interleukin-1 or tumor necrosis factor- $\alpha$. f Immunol 1989; 143: 3309-17.

10 King JIW, Bersani L, Mantovani A. Tumor necrosis factor is chemotactic for monocytes and polymorphonuclear leukocytes. F Immunol 1987; 138: 1469-74.

11 Elias JA, Gustilo K, Baeder W, Freundlich B. Synergistic stimulation of fibroblast prostaglandin production by recombinant interleukin-1 and tumour necrosis factor. f Immunol 1987; 138: 3812-6.

12 Laudanna C, Miron S, Berton G, Rossi F. Tumor necrosis factor- $\alpha /$ cachectin activates the $\mathrm{O}_{2}{ }^{-}$-generating system of human neutrophils independently of the
hydrolysis of phosphoinositides and the release of archidonic acid. Biochem Biophys Res Commun 1990; 166: 308-15. 
13 Meier B, Radekle HH, Selle S, Younes M, Sies H, Resch K Human fibroblasts release reactive oxygen species in response to interleukin- 1 or tumor necrosis factor- $\alpha$. Biochem f 1989; 263: 539-45.

14 Radeke HH, Meier B, Topley N, Floge J, Habermehi GG, Resch K. Interleukin 1-alpha and tumor necrosis factoralpha induce oxygen radical production in mesangeal cells. Kidney Int 1990; 37: 767-75.

15 Dayer JM, Beutler B, Cerami A. Cachectin/tumor necrosis factor stimulates collagenase and prostaglandin $E_{2}$ production by human synovial cells and dermal fibroblasts. F Exp Med 1985; 162: 2163-8.

16 Lehman V, Benninghoff $B$, Droge W. Tumor necrosis factor-induced activation of peritoneal macrophages is regulated by prostaglandin $\mathrm{E}_{2}$ and cAMP. $\mathcal{F}$ Immunol 1988; 141: 587-91.

17 Topley N, Floege J, Wessel K, Hass R, Radeke HH, Kaever $\mathrm{V}$, Resch $\mathrm{K}$. Prostaglandin $\mathrm{E}_{2}$ production is synergistically increased in cultured human glomerular mesangial cells by combinations of IL- 1 and tumor necrosis factor- $\alpha$. f Immunol 1989; 143: 1989-95.

18 Braegger CP, Nicholls S, Murch SH, Stephens S, MacDonald TT. Tumour necrosis factor alpha in stool as a marker of intestinal inflammation. Lancet 1992; 339: $89-91$.

19 Olson $\mathrm{AD}$, Ayass $\mathrm{M}$, Chensue $\mathrm{S}$. Tumor necrosis factor and IL1-b expression in pediatric patients with inflammatory bowel disease. 7 Ped Gastroenterology Nutr (in press).

20 MacDonald T, Hutchings $P$, Choy M, Murch S, Cook A Tumor necrosis factor and interferon-gamma production measured at a single cell level in normal and inflammed measured at a single cell level in normal and inflam

21 Murch SM, Lamkin VA, Savage MO, Walker-Smith JA MacDonald TT. Serum concentrations of tumor necrosis factor in childhood chronic inflammatory bowel disease. Gut 1991; 32: 913-7.

22 Isaacs KL, Sartor RB, Haskill S. Cytokine mRNA profile in inflammatory bowel disease mucosa detected by PCR amplification. Gastroenterology 1992; 103: 1587-95.

23 Mahida YR, Wu K, Lamming CED, Jewell DP, Hawkey CJ. Human colonic tumor necrosis factor production. Gastroenterology 1989; 96: A313.

24 Stevens C, Walz G, Zanker B, Singaran C, Lipman M, Storm T. Interleukin $6, \mathrm{IL}-1$ and tumor necrosis factor expression in inflammatory bowel disease. Gastroenterology 1990; 98: A475.

25 Lichtman SN, Sartor RB. Examining the role of inflammatory cytokines in chronic inflammatory bowel disease. f Ped Gastroenterology Nutr 1993; 16: 239-40.

26 Lawson LD, Powell DW. Bradykinin-stimulated eicosanoid synthesis and secretion by rabbit ileal components. Am f Physiol 1987; 252: G783-90.

27 Smith GS, Warhurst G, Turnberg LA. Synthesis and degradation of prostaglandin $\mathrm{E}_{2}$ in the epithelial and subepithelial layers of the rat intestine. Biochim Biophys Acta 1982; 713: 684-7.

28 Craven PA, De Rubertis FR. Profiles of eicosanoid production by superficial and proliferative colonic epithelial cells and sub-epithelial colonic tissue. Prostaglandins 1986; 32: 387-99.

29 Lecce JG, Coalson JA. Diets for rearing colstrum-free piglets with an automatic feeding device. F Anim Sci 1966 42: 622-9.

30 Argenzio RA, Liacos JA, Levy ML, Meuten DJ, Lecce JG, Powell DW. Villous atrophy, crypt hyperplasia, cellula infiltration, and impaired glucose absorption in enteric cryptosporidiosis of pigs. Gastroenterology 1990; 98:

31 Cominelli F, Nast CC, Clark BD, Schindler R, Llerena R, Eisselein VE, et al. Interleukin 1 (IL-1) gene expression, synthesis, and effect of specific IL-1 receptor blockade in rabbit immune complex colitis. F Clin Invest 1990; 886: 972-80.

32 Dunham DM, Arkins S, Edwards CK, Danter R, Kelley $\mathrm{KW}$. Role of interferon- $\gamma$ in counteracting the suppurative effect of transforming growth factor- $\beta 2$ and glucocorticoids on the production of tumor necrosis factor-a. f Leukoc Biol 1990; 48: 473-81.

33 Wuthrich KC, Peterhans E, Pauli U. The porcine tumor . 1991; 102: $171-8$.

34 Pescovitz MD, Lunney JK, Sachs DH. Preparation and characterization of monoclonal antibodies reactive with porcine PBL. F Immunol 1984; 133: 368-75.

35 Dharmsathaphorn K, McRoberts JA, Mandel KG, Tisdale LD, Masui H. A human colonic tumor cell line that maintains vectorial electrolyte transport. Am $\mathcal{f}$ Physio 984; 246: G204-8.

36 Berschneider HM. Hydrocortisone (HC) induces amiloride-sensitive, electrogenic sodium absorption in cultured porcine intestinal epithelial cells (IPEC-1). Gastroenterology 1989; 96: 41A.

37 Berschneider HM, Powell DW. Fibroblasts modulate intestinal secretory responses to inflammatory mediators. f Clin Invest 1992; 89: 484-9.

38 Granstrom E, Kindahl H. Radioimmunoassay of prostaglandins and thromboxanes. Adv Prostaglandin prostaglandins and thromboxanes. Adv Prosta

39 Spenney JG, Mize KS. Inhibition of $\mathrm{K}^{+}$ATPase by phenylbutazone and indomethacin. Biochem Pharmaco 977; 26: 1241-5.

40 Burch RM, Wise WC, Haluschka PV. Prostaglandinindependent inhibition of calcium transport by nonsteroid anti-inflammatory drugs: Differential effect of carboxylic acids and piroxicam. F Pharmacol Exp Therap 1983; 227: 84-91.

41 Marsden PA, Bellermann BJ. Tumor necrosis factor $\alpha$ activates soluble guanylate cyclase in bovine glomerula mesangial cells via an L-arginine-dependent mechanism. f Exp Med 1990; 172: 1843-52.

42 Marsden PA, Brock TA, Ballermann BJ. Glomerular endothelial cells respond to calcium-mobilizing agonists with release of EDRF. Am f Physiol 1990; 258 with release

43 Binder HJ, Foster ES, Budinger ME, Hayslett JP. Mechanism of electroneutral sodium chloride absorption in distal colon of the rat. Gastroenterology 1987; 93: 449-55.

44 Sandaram U, Knickelbein RG, Dobbin JW. pH regulation in ileum: $\mathrm{Na}^{+}-\mathrm{H}^{+}$and $\mathrm{Cl}^{-}-\mathrm{HCO}^{-}$exchange in isolate crypt and villous cells. Am f Physiol 1991; 260: G1-10.

45 Bauldry SA, McCall CE, Cousart SL, Bass DA. Tumo necrosis factor- $\alpha$ priming of phospholipase $\mathrm{A}_{2}$ activation in human neutrophils. F Immunol 1991; 146: 1277-85.

46 Currane RD, Billiar TR, Stuehr DJ, Ochoa JB, Harbrech Currane RD, Billiar TR, Stuehr DJ, Ochoa JB, Harbrecht
BG, Flint SG, Simmons RL. Multiple cytokines are required to induce hepatocyte nitric oxide production and required to induce hepatocyte nitric oxide production and

47 Berschneider HM, Goralska M. Interleukin-1 $\alpha$ (IL- $\alpha$ ) and Berschneider HM, Goralska M. Interleukin- $1 \alpha$ (IL- $\alpha$ ) and tumor necrosis factor- $\alpha$ (TNF) enhance the paracrine
modulation of intestinal epithelial $\mathrm{Cl}^{-}$secretion by fibroblasts. Gastroenterology 1992; 102: A201. 